$\xi=\mathrm{\alpha}$

\title{
Physiochemical and bacteriological analyses of selected sachet water in central Monrovia, Liberia
}

\author{
CHEA Sampson K. P. ${ }^{1 *}$, PAYE Terrance ${ }^{1}$ \\ ${ }^{I}$ Department of Biological Sciences, T. J. R. Faulkner College of Science and Technology University of Liberia \\ *Corresponding author E-mail: skpchea719@gmail.com
}

\begin{abstract}
In developing nations of the world $80 \%$ of all diseases and over $30 \%$ of death are related to drinking water. Drinking water may become contaminated during collection, handling, storage and use. Since the introduction of factory based water, their consumptions have increased severely in Liberia. Therefore, it is essential to investigate the physiochemical and bacteriological parameters of sachet water brands sold in Central Monrovia in order to ascertain whether they conform to recommended standards of portable drinking-water by the World Health Organization (WHO). This study made used of random sampling. Six samples of seven brands of sachet water were purchased randomly from provision shops. The samples were transported to the National Standards Laboratory for physiochemical and bacteriological analyses. Physiochemical parameters such as calcium, fluoride, iron, lead, turbidity and pH were checked, while Total Viable Count, coliform, and Escherichia were checked as bacteriological parameters. The calcium level of the samples ranged from $4.60-17.8$ $\mathrm{Mg} / \mathrm{L}$. All the samples had $0.00 \mathrm{Mg} / \mathrm{L}$ of fluoride. The iron level of the samples ranged from $0.11-0.39 \mathrm{Mg} / \mathrm{L}$. The lead level of the samples ranged from $0.21-0.36 \mathrm{Mg} / \mathrm{L}$. The $\mathrm{pH}$ range of the samples was from $7.00-7.01$. The turbidity of the samples ranged from $0.00-3.74$ NTU. Six of the samples showed to have 0.00 NTU for turbidity. Only sample 6 had value for turbidity. The level of turbidity measured 3.47 NTU. Sample 1, 2, 5 and 7 had no trace of viable count, coliform and Escherichia while sample 3, 4 and 6 show traces of viable count, coliform and Escherichia. Samples with Total Viable Count far above $0 \mathrm{Cfu} / \mathrm{mL}$ are considered unfit for portability. There were coliform and Escherichia detected in some samples, thereby making these samples not palatable. All of the samples had concentration of calcium. All of the samples had $\mathrm{pH}$ and fluoride that are in range with the reference standards of the World Health Organization (WHO) and Ministry of Health (MOH). All of the samples had lead and iron that were out of range of the reference standards. All of the samples showed a turbidity of 0.00 NTU except sample 3 which had turbidity of 3.74 NTU.
\end{abstract}

Keywords: Physiochemical; Bacteriological; Sachet Water; Analysis; Safe Drinking Water.

\section{Introduction}

Life began in water, and it is the single most important molecule on earth. All organisms are $70-90 \%$ water. Water is so familiar that we take it for granted, but without water, life would not exist [1]. About $70-73 \%$ of the earth is covered by water [2]. Liberia is tropical country situated in West Africa. Its landscape is occupied with enough water. Yet the provision of safe drinking water is a fundamental problem. The country has an estimated population of 4.5 million people and life expectancy at birth of 61.2 years [3]. Liberia ranks among the lowest (177 out of 188 countries) in the human development index, with $64 \%$ of its population living below the poverty line [3]. An estimated 1.1 million Liberians lack access to safe drinking water and 3.7 million lack access to improved sanitation infrastructure [4], [25].

The primary purpose of drinking water quality monitoring is to ensure the protection of public health against diseases that result when drinking water is contaminated and ingested. While drinking water is essential to the sustenance of life, an adequate, safe and accessible supply must be available for human consumption [5], [24]. As it is in many other countries, drinking water in Liberia is produced by government, private companies and communities. Of these however, water companies have, in recent times, emerged in Liberia as key suppliers of drinking water. This has not surfaced without major challenges including the need to strengthen gov- ernment capacity to monitor the quality of water produced by these rapidly emerging water companies that are producing sachet water which is being traded to the public for drinking.

As a result, the emergence and proliferation of private water enterprises operating side by side government owned utilities become inevitable. In most cases, the supply of these enterprises reaches the consumers through various water vendors including the packaged water sellers [6]. However, the quality of most packaged waters cannot be vouched for.

In Liberia, the sale and consumption of hand-filled and hand-tied polyethene bagged water was a widespread practice before the emergence of sachet (mineral) water. However, this practice was noticed to be prone to risk of contamination during production since bare hands were used in each stage of the production. For example, polyethene bagged waters, commonly called "big bag waters" were opened by mouth by blowing of air, which was a potential source of introducing bacteria. The bags were sealed by tying a knot at one end via the use of hand without any form of sterilization. The production of factory based plastic bagged water, popularly called "mineral water" was introduced in Liberia as an improvement on the hand-filled and hand-tied plastic water in 2003. Since the introduction of factory based water, their consumptions have increased severely in Liberia. Ideally, packaged water is meant to provide safe water for people. It is also meant to improve the livelihood of vendors through self-employment and reduce cholera and other water borne diseases in the country thus 
making its demand in the country insatiable. Although this is a laudable idea, current trends seem to suggest that sachet water could be a route of transmission of enteric pathogens and increased concentration of other metals. The healthy condition of these sachet water brands can be established through their physiochemical characteristics [7]. Moreover, according to WHO (2003), drinking water may become contaminated during collection, handling, storage and use [8]. Therefore, the need to carry out a scientific investigation on the physiochemical and bacteriological parameters of sachet water brands sold in Central Monrovia is necessary. It is against this backdrop that an investigation on the physiochemical and bacteriological qualities of sachet (mineral) water sold in central Monrovia was carried out to establish whether they conform to WHO recommended standard for portable water.

\section{Literature review}

The physical parameters of water quality include color, odor, appearance, taste, total dissolved solid (TDS), conductivity, turbidity and total suspended solid (TSS). The chemical parameters of water quality include $\mathrm{pH}$, Chlorides, total hardness, phosphate, nitrate, sulphate, potassium, iron, sodium, and calcium. Moreover, the bacteriological parameters of water quality are total viable count (TVC) and total coliform count. If has been observed that these parameters can affect the drinking water quality, if their values are in concentration other than the safe limits set by the World Health Organization (WHO) and other regulatory bodies [7]. Thus, the quality of drinking has been investigated regularly throughout the world by researchers and government department [9]. The wholesomeness of these selected brands of sachet water can be established through their physiochemical and microbiological characteristics [10].

Water should be free of tastes and odors that would be objectionable to the majority of consumers. Bacteriological, chemical and physical constituents of water may affect the appearance, odor or taste of the water. These constituents may have no direct health effects; however, water that is highly turbid, highly colored or has an objectionable taste or odor may be regarded by consumers as unsafe and rejected. Changes in the normal appearance, taste or odor of a drinking water supply signal changes in the quality of the raw water source or deficiencies in the treatment process and should be investigated [11]. The WHO standard for drinking water quality appearance is clear colorless (CCL). The standard for color has a highest desirable of 3.0 TCU (True Color Unit) and a maximum permissible of 15 TCU. For odor and taste, the WHO standards are set at unobjectionable [10].

Cool water is generally move palatable than warm water, and temperature will have an impact on the acceptability of a number of other inorganic constituents and chemical contaminants that may affect taste. High water temperature enhances the growth of microorganisms and may increase problems related to taste, odor, color and corrosion [10]. The maximum permitted standard of drinking water is $25^{\circ} \mathrm{C}$ [10]. Temperature between $24.6^{\circ} \mathrm{C}$ and $26.6^{\circ} \mathrm{C}$ are considered fit for consumption [12].

Total Dissolved Solids are matter suspended or dissolved in water [7]. The Palatability of water with a Total Dissolved Solid (TDS) level of less than about $600 \mathrm{mg} / \mathrm{L}$ is generally considered to be good; drinking water becomes significantly and increasing unpalatable at TDS levels greater than about $1000 \mathrm{mg} / \mathrm{L}$. the presence of high levels of TDS may also be objectionable to consumers, owing to excessive scaling in water pipes, heaters, boilers and household appliances [11].

The $\mathrm{pH}$ is a measure of the acidity, basicity and neutrality of a particular solution [7]. Although pH usually has no direct impact on consumers, it is one of the most important operational water quality parameters. Careful attention to $\mathrm{pH}$ control is necessary at all stages of water treatment to ensure satisfactory water clarification and disinfection. For effective disinfection with chlorine, the $\mathrm{pH}$ should preferably be less than 8 ; however, lower $-\mathrm{pH}$ water (approximately $\mathrm{pH} 7$ or less) is more likely to be corrosive. Failure to minimize corrosion may result in the contamination of drinking water and in adverse effects on its taste and appearance. The optimum $\mathrm{pH}$ required will vary in different supplies according to the composition of the water and the nature of the construction materials used in the distribution system, but it is usually in the range $6.5-8.5$ [11]. Low water $\mathrm{pH}$ can cause gastro-intestinal irritation in sensitive individuals. High water $\mathrm{pH}$ does not pose a health risk, but it can cause aesthetic problems, such as an alkali taste to the water that make coffee taste bitter [7].

The total viable counts (TVCs) are a simple enumeration of viable bacteria in all kinds of water. This is done by fixing the in a nutrient gel (agar), and incubating the culture plate at either $22^{\circ} \mathrm{C}$ or $37^{\circ} \mathrm{C}$ for a few days until visible colonies of individual bacterial appear. The count of colonies is equivalent to the number of bacteria in the water when the test began as the agar separation as the bacteria multiply. Each bacterium thus forms a visible colony on incubation. The number of colonies can be counted by eye. The results are expressed as colony forming units $(\mathrm{cfu}) / \mathrm{mL}$ [13]. The standard of water quality for the total coliform counts is 120 $\mathrm{cfu} / \mathrm{mL}$ [10], [22].

Coliforms are bacteria that are always present in the digestive tract of animals, including humans, and are found in their wastes. They are also found in plant and soil material. The most basic test for bacterial contamination of a water supply is the test for total coliform bacterial. Total coliform counts give a general indication of the sanitary condition of a water supply. Total coliforms include bacteria that are found in the soil, in water that has been influenced by surface water, and in human waste or animal waste. Fecal coliforms are the group of the total coliforms that are considered to be present specifically in the gut and feces of warmblooded animals. Because the origins of fecal coliforms are more specific than the origins of the more general total coliform group of bacteria, fecal coliforms are considered a more accurate indication of animal or human waste than the total coliforms. Escherichia coli (E. coli) is the major species in the fecal coliform group. Of the five general groups of bacteria that comprise the total coliforms, only E. coli is generally not found growing and reproducing in the environment. Consequently, E. coli is considered to be the species of coliform bacteria that is the best of fecal pollution and possible presence of pathogens. Most coliform bacteria do not cause disease. However, some rare strain of E. coli can cause serious illness (EPA, 2014). The standard of water quality for the total coliform counts is 0 colony forming units $(\mathrm{cfu}) / \mathrm{mL}[10]$.

\section{Methodology}

\subsection{Study setting}

This investigation was conducted in central Monrovia, the Capital City of Liberia, with about 1.1 million inhabitants. It has been observed that the terrain harbors the sale of many sachet (mineral) waters, and it is a hotspot of cultural, political and commercial activities

\subsection{Data collection}

Out of the 32 or more brands of sachet water sold in Monrovia, seven (7) brands were randomly selected. Six (6) samples of each brand were randomly selected from provision shops and vendors in the study area. The samples were packaged in black plastics and placed in a cooler, and they were transported to the National Standards Laboratory for analyses the same day.

The samples were taken to the Sample Collecting Room of the National Standards Laboratory where the physiochemical and bacteriological parameters were investigated. Four (4) of the samples from each brand were extracted at the sampling room and moved to the chemistry laboratory for immediately analysis. The other two (2) samples of each brand were stored and later taken to the microbiological laboratory the next day for analysis. The names of the samples were Kumba Bendu, Destiny Pure, Crystal 
Mineral, Pleebo Real, Mekki's Mineral, Zam-Zam, and Ducor Safe. The samples were all liquid, and they were in ambient condition. All tests were carried-out at normal room temperature $\left(25^{\circ} \mathrm{C}\right)$ and $\mathrm{RH} 55 \%$.

\subsection{Data Analysis}

\subsubsection{Physiochemical analysis}

The samples were labelled sample 1 to 7 . The laboratory apparatus were placed on the laboratory bench. Seven conical flasks were setup in parallel and each sample was placed in each flask. Each flask was labeled with the initial of the brand of water that was placed in it. The brands of water were placed on the laboratory bench in the order of the labelled conical flasks. Each brand of water was opened using a sterilized scissor and placed in the labelled conical flasks. Calcium, fluoride, iron and lead were checked using the Spectroquant 300 muti-parameter instrument The $\mathrm{pH}$ was checked using the 350 Jenway $\mathrm{pH}$ meter. Lastly, turbidity was checked using the Mrc-TU 2016 turbidity meter.

\subsubsection{Bacteriological analysis}

The samples were labelled and laid out in pairs on the laboratory bench. The media were prepared in pairs one day before the samples were brought for analysis. The green was prepared in a test tube; two for each brand. The other was prepared in a petri dish; two for each brand. The petri dishes were laid out on the laboratory bench. Two petri dishes for each brand of the sample. The petri dishes were labelled with the initial of the brands of water using a permanent marker. The green media were also labelled with the initial of the brands of water using a permanent marker. The first brand of water was sterilized and opened with a sterilized scissor. The water was placed in a graduated beaker until the $100 \mathrm{~mL}$ mark was reached. $1 \mathrm{~mL}$ of the first sample was placed in the green media in two labelled test tubes respectively and the two test tubes were taken to the volted mixer for agitation. Moreover, $1 \mathrm{~mL}$ of first sample were place on the media in two labelled petri dishes respectively. The petri dishes of sample 1 were set aside and the test tubes of sample 1 were placed on a test tube rack. This procedure was replicated for the other six (6) samples. At the end of the procedures, all the samples of various media were placed in an incubator to be incubated at $37^{0}$ for 24 hours. At the end of the incubation, the Total Viable count was obtained using ISO 4833:2003. Coliform was checked using ISO 4831:2006, and Escherichia was checked using ISO 7251:2005.

\section{Results}

The physiochemical and bacteriological parameters of the selected brands of sachet water were assessed and the results were compared with the Liberia Water Quality Standards / Guide prepared by the Ministry of Health \& Social Welfare (MOHSW) and the World Health Organization Water Reference Standards prepared by UN Department of Technical Cooperation for UNDP New York, 1987. Below are the results:

Table 1: Selected Physiochemical Parameters of Selected Sachet Water

\begin{tabular}{|c|c|c|c|c|c|c|c|c|c|}
\hline \multirow[b]{2}{*}{ Parameter } & \multirow[b]{2}{*}{ Unit } & \multicolumn{7}{|c|}{ Samples } & \multirow{2}{*}{$\begin{array}{l}\text { WHO/MOH } \\
\text { Ref. } \\
\text { Standard }\end{array}$} \\
\hline & & 01 & 02 & 03 & 04 & 05 & 06 & 07 & \\
\hline Calcium & $\mathrm{Mg} / \mathrm{L}$ & 11.9 & 16.1 & 17.8 & 6.90 & 4.60 & 9.10 & 5.00 & $\begin{array}{l}\text { Not } \\
\text { Applicable }\end{array}$ \\
\hline $\begin{array}{l}\text { Flouride } \\
\text { Iron }\end{array}$ & $\begin{array}{l}\mathrm{Mg} / \mathrm{L} \\
\mathrm{Mg} / \mathrm{L}\end{array}$ & $\begin{array}{l}0.00 \\
0.12\end{array}$ & $\begin{array}{l}0.00 \\
0.11\end{array}$ & $\begin{array}{l}0.00 \\
0.14\end{array}$ & $\begin{array}{l}0.00 \\
0.31\end{array}$ & $\begin{array}{l}0.00 \\
0.13\end{array}$ & $\begin{array}{l}0.00 \\
0.39\end{array}$ & $\begin{array}{l}0.00 \\
0.16\end{array}$ & $\begin{array}{l}\leq 1.5 \\
\leq 0.10\end{array}$ \\
\hline Lead & $\mathrm{Mg} / \mathrm{L}$ & 0.27 & 0.27 & 0.21 & 0.30 & 0.28 & 0.32 & 0.36 & $\leq 0.10$ \\
\hline $\mathrm{pH}$ & $-\log$ & 7.00 & 7.00 & 7.00 & 7.01 & 7.01 & 7.00 & 7.00 & $6.5-8.0$ \\
\hline Turbidity & NTU & 0.00 & 0.00 & 0.00 & 0.00 & 0.00 & 3.74 & 0.00 & $\begin{array}{l}\text { Not } \\
\text { Applicable }\end{array}$ \\
\hline
\end{tabular}

Sample Key: Kumba Bendu (01), Destiny Pure (02), Crystal Mineral (03), Pleebo Real (04), Mekki's Mineral (05), Zam-Zam (06), Ducor Safe (07).

$\mathrm{WHO}=$ World Health Organization $\quad \mathrm{MOH}=$ Ministry of Health $\quad$ ISO $=$ International Standards Organization $\quad \mathrm{Cfu} / \mathrm{mL}=\mathrm{Colo}-$ ny forming unit per milliliter $\mathrm{Mg} / \mathrm{L}=$ Milligram per Liter

Table 2: Selected Bacteriological Parameters of Selected Sachet Water

\begin{tabular}{|c|c|c|c|c|c|c|c|c|}
\hline \multirow{2}{*}{$\begin{array}{l}\text { Parameter } \\
\text { (Unit) }\end{array}$} & \multicolumn{7}{|l|}{ Samples } & \multirow{2}{*}{$\begin{array}{l}\text { WHO/MOH } \\
\text { Ref. } \\
\text { Standard } \\
\end{array}$} \\
\hline & 1 & 2 & 3 & 4 & 5 & 6 & 7 & \\
\hline $\begin{array}{l}\text { Total } \\
\text { Viable Count } \\
\text { (Cfu/mL) }\end{array}$ & $<1.0 \times 10^{0}$ & $<1.0 \times 10^{0}$ & $1.7 \times 10^{2}$ & $1.5 \times 10^{2}$ & $<1.0 \times 10^{0}$ & $2.0 \times 10^{0}$ & $<1.0 \times 10^{0}$ & $0 \mathrm{Cfu} / \mathrm{mL}$ \\
\hline $\begin{array}{l}\text { Coliform } \\
(\mathrm{Cfu} / \mathrm{mL})\end{array}$ & N.D. & N.D. & $\mathrm{D}$ & $\mathrm{D}$ & N.D. & $\mathrm{D}$ & N.D. & $0 \mathrm{Cfu} / \mathrm{mL}$ \\
\hline $\begin{array}{l}\text { Escherichia } \\
\text { (Cfu/mL) }\end{array}$ & N.D. & $<1.0 \times 10^{\circ}$ & $\mathrm{D}$ & $\mathrm{D}$ & N.D. & D & N.D. & $0 \mathrm{Cfu} / \mathrm{mL}$ \\
\hline
\end{tabular}

Sample Key: Destiny Pure (1), Crystal Mineral (2), Pleebo Real (3), Zam-Zam (4), Kumba Bendu (5), Mekki’s Mineral (6), Ducor Safe (7)

WHO = World Health Organization $\quad \mathrm{MOH}=$ Ministry of

Health

ISO = International Standards Organization $\quad \mathrm{Cfu} / \mathrm{mL}=$ Colo-

ny forming unit per milliliter

$\mathrm{Mg} / \mathrm{L}=$ Milligram per Liter N.D. $=$ Not Detected

$\mathrm{D}=$ Detected

\section{Discussions}

Table 1 shows the physiochemical parameters of the selected brands of sachet water that were analyzed. The parameters that were checked are calcium, fluoride, iron, lead, $\mathrm{pH}$ and turbidity.
The calcium level of the samples ranged from $4.60-17.8 \mathrm{Mg} / \mathrm{L}$. Sample 5 had the lowest concentration of calcium representing $6 \%$, while sample 3 had the highest concentration of calcium representing 25\%. National Research Council [14] noted that calcium is one of the essential dietary minerals that drinking water usually supplies. Moreover, similar study conducted in Nigeria by J. C. Onweluzo and C. A. Akuagbazie titled Assessment of the Quality of Bottled and Sachet Water Sold in Nsukka Town stated that 76\% of the water brands analyzed showed relatively high level of calcium [15]. However, the existing Liberian water quality standards did not include calcium as one of its parameters. Therefore, this parameter is not applicable in Liberia. 
All of the brands of sachets water showed no trace of fluoride. All the samples had $0.00 \mathrm{Mg} / \mathrm{L}$ of fluoride. This value was in range with the reference standards of the World Health Organization and Ministry of Health which is $\leq 1.5 \mathrm{Mg} / \mathrm{L}$.

The iron level of the samples ranged from $0.11-0.39 \mathrm{Mg} / \mathrm{L}$. Sample 2 had the lowest concentration of iron representing 11\%, while Sample 7 had the highest concentration of iron representing $29 \%$. $100 \%$ of the samples showed concentration of iron that was out of the range of reference standards of the World Health Organization and Ministry of Health which is $\leq 0.10 \mathrm{Mg} / \mathrm{L}$. Results from Taiwo et al. study conducted in this same light in 2012 showed some samples that had traces of iron, while others were free of the element [16]. The presence of iron in substantial quantities can make the water unsuitable for food processing [17].

The lead level of the samples ranged from $0.21-0.36 \mathrm{Mg} / \mathrm{L}$. Sample 3 had the lowest concentration of iron representing $8 \%$, while sample 6 had the highest concentration of calcium representing 29\%. $100 \%$ of the samples showed concentration of iron that was out of the range of reference standards of the World Health Organization and Ministry of Health which is $\leq 0.10 \mathrm{Mg} / \mathrm{L}$. Onuh and Isaac stated that the presence of lead in water indicated low $\mathrm{pH}$ which lead to corrosion of pipes releasing the metal into the water [18].

The $\mathrm{pH}$ range of the samples was from $7.00-7.01$. Sample 1, 2, 3, 6 and 7 had the lowest $\mathrm{pH}$ of 7.00 representing the lowest $\mathrm{pH}$ value obtained. Sample 4 and 5 had the $\mathrm{pH}$ of 7.01 representing the highest $\mathrm{pH}$ value obtained. $100 \%$ of the samples showed $\mathrm{pH}$ values that were in the range of reference standards of the World Health Organization and Ministry of Health which is $6.5-8.0$ Taiwo et al reported in similar study conducted in Nigeria that all of the samples had $\mathrm{pH}$ values that were in permissible limits.

The turbidity of the samples ranged from $0.00-3.74$ NTU. Six of the samples were observed to have 0.00 NTU. Only sample 6 was the highest (3.74 NTU). However, the existing Liberian water quality standards did not include turbidity as one of its parameters. Therefore, result shows that the parameter is not applicable. Nevertheless, a study conducted in Nigeria titled Physio-Chemical and Bacteriological Analyses of Sachet Water Samples in Abeokuta Metropolis guarantees that these results are in accordance with recommended standards [16], [23].

Table 2 shows the bacteriological parameters of the selected brands of sachet water that were analyzed. The parameters that were checked are Total Viable Count (TVC), coliform and Escherichia. The Total Viable Count of the samples range from $<1.0 \mathrm{x}$ $10^{0}-1.7 \times 10^{2} \mathrm{Cfu} / \mathrm{mL}$. Sample $1,2,5$ and 7 had no trace of viable count representing $57.14 \%$ of the table's TVC result while sample 3, 4 and 6 showed traces of viable count also representing $42.84 \%$ of the table's TVC result. Sample 3 has the highest TVC of $1.7 \times 10^{2} \mathrm{Cfu} / \mathrm{mL}$, and sample 6 has the lowest TVC of $2.0 \mathrm{x}$ $10^{0} \mathrm{Cfu} / \mathrm{mL}$. The reference standard of the World Health Organization and Ministry of Health for TVC is $0 \mathrm{Cfu} / \mathrm{mL}$. In Nsukka town, similar study conducted showed brands of water had viable plate count above $100 \mathrm{Cfu} / \mathrm{mL}$ [15]. Fecal contamination of drinking water has a very serious health implication [19]. Therefore, the results from sample 1, 2, 5 and 7 are acceptable, while the results from sample 3, 4 and 6 are not acceptable because drinking water should contain no viable count.

The results for coliform of the samples ranged from detected to not-detected. Sample 1, 2, 5 and 7 had no trace of coliform representing $57.14 \%$ of the table's coliform result, while sample 3,4 and 6 showed traces of coliform also representing $42.84 \%$ of the table's coliform result. The reference standards of the World Health Organization and Ministry of Health for coliform are 0 $\mathrm{Cfu} / \mathrm{mL}$. This means that coliform should not be detected in drinking water. In this same light, a study conducted by Ndamitso in 2013 showed some samples that were not fit for consumption because they had high coliform counts [6]. Therefore, the results from sample $1,2,5$ and 7 are acceptable, while the results from sample 3, 4 and 6 are not acceptable.

The results for Escherichia of the samples ranged from detected to not-detected. Sample 1, 2, 5 and 7 had no trace of Escherichia representing $57.14 \%$ of the table's Escherichia result, while sample 3, 4 and 6 showed traces of Escherichia also representing $42.84 \%$ of the table's Escherichia result. The reference standards of the World Health Organization and Ministry of Health for Escherichia are $0 \mathrm{Cfu} / \mathrm{mL}$. This means that Escherichia should not be detected in drinking water. Likewise, a study conducted in Minna, Niger State reported that during the study E. coli was isolated [6]. The pathogen was probably transferred into the samples from the environment especially through sewage and other humic matter or sources related to unhygienic conditions $[20,21]$. Therefore, the results from sample 1, 2, 5 and 7 are acceptable, while the results from sample 3, 4 and 6 are not acceptable.

\section{Conclusion}

This study analyzed the physiochemical and bacteriological parameters of seven (7) brands of sachet water that were randomly purchased from provision shops in central Monrovia. The parameters analyzed were calcium, fluoride, iron, lead, $\mathrm{pH}$, turbidity, Total Viable Count, coliform and Escherichia. The brands of sachet water were Kumba Bendu, Destiny Pure, Crystal Mineral, Pleebo Real, Mekki's Mineral, Zam-Zam, and Ducor Safe. Some samples in this study (sample 3, 4 and 6) had Total Viable Count far above $0 \mathrm{Cfu} / \mathrm{mL}$, they are considered unfit for portability. Moreover, there were coliform and Escherichia detected in sample 3, 4 and 6, thereby making these samples not palatable. They are considered not palatable because they might cause water borne diseases. Also, all of the samples had concentration of calcium which is nutritionally essential with sample 5 having the lowest concentration of $4.60 \mathrm{mg} / \mathrm{L}$, and sample 3 having the highest concentration of $17.8 \mathrm{mg} / \mathrm{L}$. All of the samples had $\mathrm{pH}$ and fluoride that are in range with the reference standards of the World Health Organization and Ministry of Health. All of the samples had lead and iron that are out of range of the reference standards of the World Health Organization and Ministry of Health. All of the samples showed a turbidity of 0.00 NTU except sample 3 which had turbidity of $3.74 \mathrm{NTU}$.

\section{References}

[1] Mader, S. S. (2007). Essentials of Biology. New York: The McGraw - Hill Companies, Inc.

[2] Acheampong, P. K., \& Dollar, J.

[3] (2014).Aki-Ola Series: Biology for Senior High Schools in West Africa. Accra: Aki-Ola Publications Company Limited.

[4] Liberia Institute of Statistics and Geo-information Services (LIGIS) (June 2008). National Population and Housing Census: Preliminary Results. Government of the Republic of Liberia.

[5] African Development Bank Group (April, 2010). Urban Water Supply and Sanitation Project: Liberia. Project Appraisal Report.

[6] National Public Health Institute of Liberia (June, 2010) Drinking Water Analysis routine Survey in Monrovia and its environs.

[7] Ndamitso, M. M., Idris, S. ,Likita M. B.,Tijani J. O., Ajai A. I. and Bula A. A. , (March 2013). Physio-chemical and Escherichia coli assessment of selected sachet water produced in some areas of Minna, Niger State, Nigeria. International Journal of Water Resources and Environmental Engineering. 5(3): 134-140.

[8] Hinneh D. C. K. (2015). Qualitative Analysis of Some Physical Parameters in Selected Sachet Water in Central Monrovia, Liberia. (Unpublished, University of Liberia)

[9] Havelaar A. H., \& Melse J. M., (2003). Qualifying Public Health Risk in the WHO Guidelines for Drinking-Water Quality. A burden of Disease Approach. RIVM Report 734301022.

[10] Rahmanian, N., Ali, S. H. B., Homayoonfard, M., Ali, N. J., Rehan, M., Sadef, Y., and Nizami, A. S. (2015). Analysis of Physiochemical Parameters to Evaluate the Drinking water Quality in the State of Perak, Malaysia. Journal of Social Sciences. 6(3): $1-10$. https://doi.org/10.1155/2015/716125.

[11] World Health Organization (2012). Guidelines for Drinking Water Quality. Geneva: World Health Organization.

[12] World Health Organization (2011). Guidelines for Drinking Water Quality fourth Edition. Geneva: World Health Organization.

[13] Ahimah, J. K., and Ofosu, S. A. (May, 2012). Evaluation of quality of sachet water vended in the New Juaben Municipality of Ghana. 
International Journal of Water Resources and Environmental Engineering. 4(5): $134-138$.

[14] Hurst M. (2012). Bacteria in Bottled Watercoolers - The Significance of Total Viable Counts (TVCs) 1 www.watercoolerseurope.eu.

[15] NRC (1989). National Research Council, Food and Nutrition Board. Recommended Dietary Allowances, 10th ed. Washington, D.C. National Academy of Food sciences.

[16] Onweluzo, J. C., Akuagbazie, C. A., (2010). Assessment of the Quality of Bottled and Sachet Water Sold in Nsukka Town. AgroScience Journal of Tropical Agriculture, Food, Environment and Extension. (9) 104-110.

[17] Taiwo A. A., Idowadare O., Landre-Iyanda Y.A., Jolaoso A.A Jiboku O. O., Ijoala T.O., Taiwo A.G., (2012). Physio-chemical and Bacteriological Analyses of Sachet water samples ion Abeokuta Metripolis. Global Advanced Research Journal of Agricultural Science. 1 (1) 001-006.

[18] Oyeku O. M., Omowunmi O. J., Kupoluyi C. F., Toye O.E, (2001) Wholesomeness studies of Water Produced and Sold in Plastic Sachets (Pure Water) in Lagos Metropolis. Nig., Food J. (19), 63-69.

[19] Onuh J. O., Isaac V. U., (2009). Physio-Chemical and Microbiological Quality of water Sources from some major Towns in Igala Land. Nigeria Food Journal 27, (2), 66-72. https://doi.org/10.4314/nifoj.v27i2.47474.

[20] Banwart, G. J. (2004). Basic Food Microbiology, 2nd Edition. Chapman \& Hall Inc., New York.

[21] Environmental Protection Agency (EPA) (2002). US Environmental Protection Agency Safe Drinking Water Act Amendment. www. Epa.gov/safe water/mcl.Html.

[22] Environmental Protection Agency (EPA) (2014). Coliform Bacteria in Drinking Water Supplies. New York: New York State Department of Health.

[23] World Health Organization (2003).Guidelines for Drinking Water Quality. Geneva: World Health Organization.

[24] Dada A., \& Ntukekpo D. S. (1997): Pure Water; How Safe? Ultimate Water Technology and Environment. 1(3): 8-11.

[25] Teshamulwa O. (2007). Water Quality and Business Aspects of Sachet-vended Water in Tamale, Ghana. A Thesis on Master Degree in Civil and Environmental Engineering at Massachusetts Institute of Technology.

[26] Tortora, G. J., \& Derrickson, B. (2012). Principles of Anatomy \& Physiology 13th edition. New Jersey: John Wiley \& Sons Inc. 